Huzenko D. V., Postgraduate Student

Donbass State Engineering Academy

Kramatorsk, Donetsk region, Ukraine

DOI: https://doi.org/10.30525/978-9934-26-028-5-22

\title{
APPROACHES TO IMPROVING BUSINESS PROCESSES IN AN ENTERPRISE
}

Continuous improvement of business processes directly affects the quality of products, services provided and increase profits. Awareness of the importance of this issue gave rise to the first wave of improving the efficiency and quality of enterprises, which took place in 80-90-ies of XX century. These programs were aimed at improving the quality of their tasks by employees. Then the following methods of efficiency increase were introduced in work:

- command brainstorming method to identify problems;

- setting priorities in the performance of works;

- work on attracting employees;

- creation and maintenance of corporate image.

These methods have proven to be the best, despite the fact that they had several disadvantages:

- $80 \%$ of problem situations can be solved only by the management of the enterprise;

- high level of costs due to the fact that these measures require the involvement of all employees of the enterprise;

- their low applicability in organizations operating in the field of services.

These shortcomings contributed to the beginning of new changes in order to improve the efficiency and quality of production.

Currently, the basics of business process management are works on their description, optimization and regulation. Such projects, as a rule, affect a rather large list of employees of the enterprise, whose job responsibilities can differ significantly.

In the process management process, the organization is seen as a mechanism that includes many business processes, the coherence of 
which contributes to efficient production, result-oriented, which, in turn, has some value in the market.

In modern process management there are the following approaches to improving business processes in the enterprise:

1) a step-by-step approach based on the well-known model of continuous process improvement, called the "Shuhat-Deming cycle" or "PDCA" (Plan, Do, Check, Act) [1];

2) the cardinal approach described in the book by Michael Martin Hammer and James Champy and known for its methods of business reengineering processes [2].

The basis of this approach is to consider the activities of the organization "from scratch", and the development of more efficient business processes. The concept of this approach is the continuous improvement of business processes of the enterprise.

The above approaches are based on the general methodology of process management, the main aspects of which are:

- description of process boundaries;

- description of the process itself;

- setting checkpoints in processes and more.

Despite the similarity of these approaches, they have a number of differences.

There are five main methods of improving business processes:

- method of rapid decision analysis ("FAST");

- benchmarking process;

- redesign of the process;

- process engineering;

- process reengineering.

The method of rapid decision analysis involves the creation of a process improvement group, which for one or two days studies the current state of the process and then for ninety days develops a strategy to improve the process. The method of rapid decision analysis is based only on the intuitive method of decision-making and, as a rule, chooses as a strategy to improve the processes of reducing costs and duration of the process. 
The advantage of this method is the speed of generating ideas and decision-making, the implementation of minimal costs for the implementation of the strategy, customer focus.

Disadvantages of this method:

- locality of the researched process;

- lack of understanding of the relationship of the studied process with other processes in the enterprise;

- the possibility of ineffectiveness of the adopted strategy to improve the process in the long run.

However, this method of improvement is widespread among business leaders.

The benchmarking process is a comparative analysis of this company with leading companies operating in the same industry. The purpose of the analysis is to identify the missing qualities in this company to achieve competitiveness.

The advantage of this method is a relatively short analysis time, as well as low financial costs and labor costs. When choosing this method of improving the processes in the enterprise, it should be borne in mind that along with copying the positive qualities of leading companies, there is a possibility of transfer and mistakes hidden behind a successful image.

Another method of process improvement is process redesign. Most often, this method share with benchmarking processes.

Process redesign is to focus on one, often well-functioning process, but requires change or improvement at the request of the consumer.

After carrying out the above stages of work, the best developments in the field of computerization and automation of production are usually used.

During the analysis of problems of improvement of processes of activity of the organizations the general characteristic features of various methods reflecting a number of requirements to improvement of processes are revealed:

- improved processes must meet modern requirements for quality, service, flexibility and low cost, and be understandable. Despite the 
integration of work, business processes retain the requirement of simplicity of a specific task;

- the supplier of the process should be part of the changing process or organization. It is achieved as a result of establishing partnerships with participants in the process or involving external suppliers to perform certain parts of the process;

- alternative versions and variants of processes are necessary that is possible at process modeling. To confirm the concept, the developed process must correspond to the formulated views;

- increasing decision-making powers responsible for the process increases autonomy and reduces bureaucracy in management;

- expanding the use of information technology to ensure effective management decisions;

- optimizing the use of resources: freeing up employees and combining different functions, as a result of which entire units are removed from the process;

- real-time data analysis and support for organizational change.

\section{References:}

1. Neave H.R. The Deming Dimension. 1st Paperback Edition. SPC PRESS, 1990 (Russ. ed.: Prostranstvo doktora Deminga. Printsipy postroeniya ustoichivogo biznesa. Moscow, Al'pina Biznes Buks Publ., 2005, 369 p.).

2. Hammer M., Champy J. Reengineering the Corporation: A Manifesto for Business Revolu- tion (Collins Business Essentials). HarperBusiness, 2006 (Russ. ed.: Reinzhiniring. 